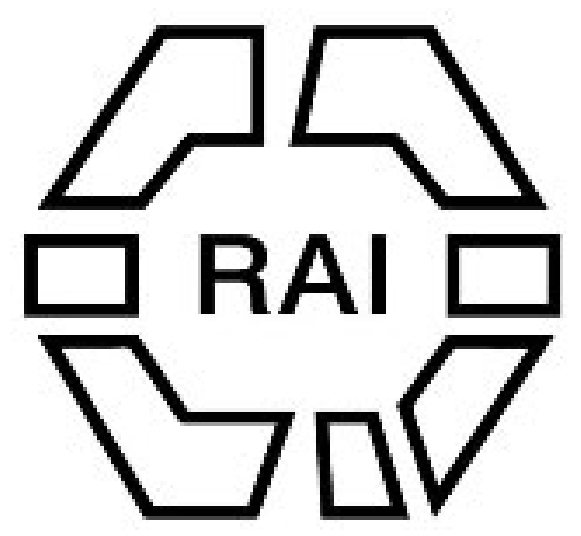

The Present Condition of the Native Tribes in Bechuanaland.

Author(s): C. R. Conder

Source: The Tournal of the Anthropological Institute of Great Britain and Ireland, Vol. 16 (1887), pp. 76-96

Published by: Royal Anthropological Institute of Great Britain and Ireland

Stable URL: http://www.jstor.org/stable/2841744

Accessed: 14/06/2014 23:32

Your use of the JSTOR archive indicates your acceptance of the Terms \& Conditions of Use, available at http://www.jstor.org/page/info/about/policies/terms.jsp

JSTOR is a not-for-profit service that helps scholars, researchers, and students discover, use, and build upon a wide range of content in a trusted digital archive. We use information technology and tools to increase productivity and facilitate new forms of scholarship. For more information about JSTOR, please contact support@jstor.org.

Royal Anthropological Institute of Great Britain and Ireland is collaborating with JSTOR to digitize, preserve and extend access to The Journal of the Anthropological Institute of Great Britain and Ireland. 
From the Academy.-Atti della Reale Accademia dei Lincei. Serie Quarta. Vol. II. Fas. 4.

Bulletin de l'Academie Impériale des Sciences de St. Pétersbourg. Tom. XXX. No. 3.

From the Institute-Proceedings of the Canadian Institute. Third series. Vol. III. Fas. 3. No. 144.

From the Institution.- Journal of the Royal Institution of Cornwall. Vol. VIII. Part 4.

From the SocierT.- Journal of the Society of Arts. Nos. 1738, 1739.

- Proceedings of Society of the Antiquaries. Second Series. Vol. X. No. 3.

From the Editor. - Nature. Nos. 854, 855.

Science. No. 160.

L'Homme. 1886, No. 3.

The following paper was read by the author:-

\section{The Present Condition of the Native Tribes in Bechuanaland.}

By C. R. Conder, Captain R.E.

THE subject on which I have been invited by the president to read a paper before you is that of the present condition of the native tribes in Bechuanaland. During the recent expedition under Sir Charles Warren, my duties, as Boundary Commissioner and otherwise, led me to study, to the best of my ability, the character and condition, especially of the Batlaping and Barolong divisions of the Bechuana Kafirs; and in addition to the result of personal enquiry, I obtained a good deal of information from such residents as have longest dwelt among these tribes, especially from the Rev. W. Ashton, a friend of Dr. Livingstone, who has lived in Bechuanaland since 1843, and from the Rev. J. Mackenzie, who dwelt for many years at Shoshong, the chief place of the great Bamangwato chief, Kama. Very valuable information has also become lately available, in the voluminous Blue-Book on Native Laws and Customs, published by the Government of Cape Colony. From such sources I collected information, which I will endeavour to put in such a form as to afford an answer-so far as I am able to render one-to the majority of the questions contained in the valuable "Anthropological Notes and Queries," prepared by the Committee of the British Association.

Before proceeding, however, to the main question, a few words may be said concerning the surrounding tribes; and as to the present proportions of the various divisions of the Bechuana. 
The new Crown colony of Bechuanaland, of which I laid down the eastern boundary, is situated west of the Transvaal, and north of Griqualand West. It includes the territory of the Batlaping and Barolong tribes of the Bechuana, and that of the Batlaros, lying further west, near the border of the Kalahari Desert. North of the colony, a large country, inhabited by the Bangwaketse, the Bakwena, the Bakatla, and the Bamangwato, stretches towards the Zambesi. The remnants of the Makalaka (akin to the Basuto) intervene between the northern Bechuana, and the Matabele (a Zulu race), who occupy a rich country, north of the Transvaal. North-east of the Matabele is Mashonaland, a country rich in minerals, extending to the Zambesi. Bechuanaland itself is a pastoral country, consisting of a great plateau, 4,000 feet above the sea, with a fine climate, and grazing lands, said in some cases to be among the finest known in South Africa. Within the limits of the Crown colony there is but little bush, and the country is certainly very superior in fertility to the colonial possessions south of the new colony. The principal drawback is the insufficiency of water; but the rainfall is in many years plentiful, and a small expenditure in public works would greatly improve the country in this respect. The streams during the summer rains become impassable rivers, but the water soon rushes off to the Vaal River, or is lost in the Kalahari Desert.

It is extremely difficult to obtain reliable statistics, as to the numbers of the native population in Bechuanaland. War has not materially affected the question, and the large native families, under a polygamous system, tend to give a rapid increase in numbers. On the other hand, recent famines, and increasing disease, tend to reduce these numbers; while the inroads of white men lead to migrations, which result in decrease of native numbers in the south and east, and corresponding increase in the north and west. It was part of my duty to collect such statistics as were available, but the results were very rough. The fighting men of the Batlaping may, I think, be stated at some 3,000 in all. The Barolong within the colony have, perhaps, 2,000 fighting men; those within the Transvaal were more numerous, but are now dispersing in all directions. Of the northern tribes, the Bamangwato is the largest, and Kama, their chief is said to have 5()0 mounted men armed with rifles. In addition to the Bantu races, just enumerated, there were till quite lately some 5,000 Korannas, inhabiting the neighbourhood of Mamusa, now within the Transvaal. This settlement has been attacked by the Boers since the return of the expedition. The chief (David Massouw) and 100 men of the Korannas are said to have been killed, and many virtual slaves (or apprentices as they are called) have been made. The settle- 
ment seems, in fact, to have been broken up and the land reserved to the natives to have been confiscated.

A rough table of the population would give the following results :-

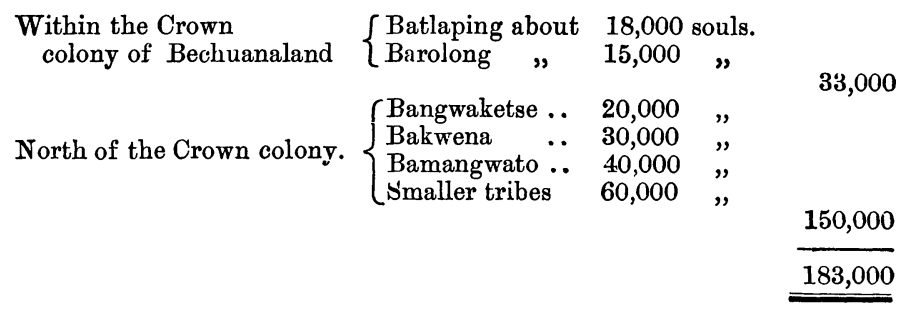

I see reason, however, to suppose that these proportions will further be modified by the disappearance of numbers of the Batlaping,' in consequence, partly of migration, partly of starvation, from which this unfortunate tribe was suffering when last I visited them at Taung.

As regards the Korannas, they are a Hottentot people, and I only came in contact with them in their locations in Barkly West and at Christiana, in the Transvaal. I was very much struck with the strongly Turanian type of the race. The broad cheek bones, the small eyes, wide apart and slightly oblique, the small mouth (somewhat projecting) and short nose, and even the colour, which is much lighter than that of the Kafirs, called to my mind both the Japanese and also the 'Turkish peasantry of Asia Minor.

I have heard it stated that the practice of excision, which occurs among the Copts and, I believe, among the Abyssinians, is also existent among the Korannas, as well as circumcision.

Both sexes color their hair with black lead, their faces with red lead, even when wearing European clothing. They consider that this renders them more beautiful, like the Zulus who paint themselves white for the same reason.

As regards the Matabele my duties did not permit of my visiting their country. A mission under Lieut. Haynes, R.E., was sent to the capital Gobilawayo to visit the Matabele king, Lobengula, with a letter from Sir C. Warren. This officer would, I think, be able-judging from my conversations with him-to give valuable information as to this warlike and important tribe.

The Matabele were originally Zulus, who, being unsuccessful in war, under Mosilikatse, were afraid to reappear before the

1 Sir G. Campbell called attention in discussion to the sparsity of the population, a fact which, of course, ought to render it all the easier to find lands for both natives and white men. 
terrible Chaka. They settled in the Transvaal and were driven thence to their present country by the Boers. Their name in Sechuana means "naked" and is due, not to the fact that they are lightly clad, but because they offend Bechuana ideas of decency, not wearing the small fur apron which men and boys always wear among the Bechuana, even when they have no clothes. The Matabele on the contrary wear a wooden box like that of the Zulus. The numbers of the Matabele have been recruited by the education of slaves from among the Makololo, Makalaka and even Bamangwato. The old Zulu type is rapidly dying out through this infusion of Basuto and Bechuana blood. and the warlike prowess of the Matabele is also decaying, so that a regiment defeated near Lake N'gami was not ashamed only last year to return to the King. It is probable that the great chief Kama is strong enough, if supported, and protected from Boer encroachments, to keep the Matabele at home. The latter are moreover well affected to the English.

I now turn to a description of the Batlaping and Barolong, basing my observations on the British Association Queries so far as I am able to deal with them. I was, however, unable to take any measurements of natives or any exact notes concerning colour, anatomy, or physiology. There is great variety in the shades of colour, but it seems that those of the purest blood are the darkest, judging from the chiefs. It is said also that the colour of the northern tribes is deeper than that of the southern, and the eyes larger. As regards odour I can attest that this increases in consequence of violent exertion.

The language of the Bechuana tribes is well known as a branch of the Bantu group. There are no clicks in Sechuana, but the Batlaping on the south are said to have contracted the habit of introducing clicks in some words in consequence of Hottentot influence. The sound represented by $\mathrm{Tl}$ as in Tlapi, "a fish" (whence Batlaping or " fish people") approaches a click. The name as will appear later may be connected with a former worship of the fish. The greatest peculiarity which I noticed was, however, the intonation of the language, which is only caught after long residence, and which contrasts strongly with the energetic enunciation of Orientals. Sechuana is a very melodious and liquid language, and the speech of the natives is full of poetic imagery, which is admired so much as to form a distinct feature in their public speaking.

Their confusion of the letters $D, L$, and $R$, is also remarkable. They can distinguish B and P which to an Arab sound the same, but which the Turks distinguish. The Sechuana $P$, indeed, is highly emphatic, resembling that of the Irish as in their pronunciation for instance of the word "ppig"; but the Sechuana word for 
God may be written Modimo, Morimo, or Molimo, and the blue wildebeest (or gnu) is called Phudomo, Pulomo, or Puromo either sound being recognised by a native. It must be remembered that even the early Greeks did not always distinguish $\mathrm{L}$ from $\mathrm{R}$, and the hieroglyphic sign is the same in Egyptian for these two letters. In the east however, $\mathrm{D}$ is confused with $\mathrm{T}$ rather than as among the Bechuana with $\mathrm{L}$ or $\mathrm{R}$.

The Sechuana language, I am told, does not possess any true numerals above six. Seven is "shupa," meaning "look out," and being the name of the forefinger. The word for eight means "two fingers down," nine is "one finger down." Ten is "completion," eleven "completion one finger up." When therefore we come to twenty eight we get the clumsy form " two completions two fingers down."

The traditions and customs of the Bechuana point to their migration from the north-east. The old tribe of the Bahrutsi is still, I believe, not extinct, and an offering of first fruits by Bechuana chiefs to the chief of this tribe seems to show that they are acknowledged as the parent stock. The Barolong have inhabited their country from time immemorial. The stone krantzes which they erected as fortifications against the Zulus under Chaka, I have found all along the present border of the new colony. One division of the tribe migrated into the Orange Free State and returned thence within the memory of middleaged men; first inhabiting Taung, which now belongs to the Batlaping, who originally lived further west; and afterwards under Moshette, settling at Kunana, a very large native town now placed in the Transvaal. This town is again being deserted by the Barolong.

There seems reason to suppose that the physique of the Bechuana tribes in the south is steadily deteriorating. This is due clearly to the influence of the whites-to the breaking up of the old social system, the laws and customs of which were well adapted to native life; and to the introduction of bad brandy and syphilis. It is thought that the adoption of European clothing has affected the health of the people, but there are clear indications that the asthma, consumption and lung diseases from which the natives suffer are congenital, and, I think, they should rather be ascribed to the excesses of the parents on whom the white men have had a disastrous influence. We have been told lately that the natives are only allowed to buy "ginger pop." If this is the case, I can only say that ginger beer in South Africa produces symptoms indistinguishable from those due to the consumption of brandy; and I have seen brandy drunk by natives in quantities which white men could not consume. 
As regards the morality of the people, their indifference to the conduct of the women is very astonishing to any traveller accustomed to Orientals. Some missionaries admit that the morality of mission stations is inferior to that of the old Pagan days. There is a simple explanation of this, as shown by the Blue-Book above noticed. Some missionaries discountenance the old native custom of giving a certain number of cows to the father of a bride, which they regard as equivalent to buying the wife, though this is not the native view. The consequence is that the native girls have no longer a market value, and the control exerted over them by their parents, and especially by the mothers, is relaxed. The morality of the natives after marriage is, on the other hand, probably improved by the influence of the very able and energetic men who accompanied and succeeded Dr. Moffat. The natives are said to be affectionate and fond of their children, and they certainly possess a love of justice and fair play and ideas of right and law which should commend them to Englishmen. Unfortunately, the colonial population have not upheld British reputation in this respect, and the natives draw a sharp distinction between the Britishchiefly known to them as soldiers or missionaries, and the colonials-traders and speculators. The prohibition of the sale of spirits is strictly enforced by such chiefs as Montsiwa and Kama who have learned that the introduction of brandy means the destruction of the tribe. This wise prohibition is clearly due to missionary influence.

Under the head of psychology I may note that the Bechuana appear to be an intelligent people. They easily learn when taught, to read, write, and cypher; they are even able to draw maps (I possess a sketch of country by one of the Barolong) and Sechele, chief of the Bakwena, sent his sons to Cape Town to school, and introduced convict labour in his country in imitation of Cape laws. They are, however, slow in their mental operations, as in their movements, and ponder long before answering, thus forcibly contrasting with Oriental volubility. That they are courageous has often been proved; they are, however, neither honest nor truthful as a rule, and small thefts are common. They are fond of giving long and rambling dissertations on trivial subjects and their deliberations in council are endless.

As regards astronomy, they appear to conceive of a firmament like that of the Babylonians, and they say that the sun travels under the earth at night. Some old people still alive have, I am told, heard the noise which the sun makes during this nocturnal journey. They have, it appears, a native calculation of the year, though I am unable to say whether this is lunar or 
solar. They have ceremonies connected with the new moon, and on moonlight nights they sit in the kotlas or village yards singing and dancing and drinking Kaffir beer. They also have harvest festivals with dances.

The ordinary native food is a sort of porridge, made of mealies or of Kaffir corn. They do not appear to make bread. They are great flesh eaters, and in addition to game will, when hungry, eat almost any kind of dead animal. I have seen them eating a mule which died of pneumonia. The Kaffir corn makes a sort of stupefying beer, but can only be indulged in by chiefs, except at the great feasts. The natives often ask for tobacco, and smoke short European pipes. They are also said to smoke a kind of hemp. I believe none of the Bechuana tribes eat fish even when living near rivers.

Mr. Ashton gave me information as to the eating of locusts by the Batlaping. The natives go by night with great bags to catch the sleeping locusts. They boil them in large iron pots, then lay them out to dry. When dried, the locusts are winnowed, the wings, legs, and head being blown away like chaff. The bodies can be kept for a considerable time. The eating of locusts is said to give a peculiar smell to those who devour them in quantities, but the natives are so fond of this food that a visitation by locusts, which ruins the white man, is rather welcomed by the Bechuana.

The frequent droughts in Bechuanaland often reduce the smaller tribes to living on berries of the Moretlwa (Grewia fava) and Mohatla (Tarchonanthus). The Makalahari (or "poor men") and the bushmen who are slaves of the Bechuana in the towns live on game and on roots. Their tribute consists of skins, and of certain parts of animals killed.

A number of the Barolong and the Bakwena and Bamangwato now profess some kind of Christianity. I think that it is certain that in some cases-as, for instance, the great and honest Kama-this profession is sincere. The Batlaping at Taung are pagans, and Montsiwa, chief of the Barolong of Mafeking (or more correctly, Mahiking), remains a pagan, though tolerating Christianity among his people.

Previous to the introduction of Christianity, the Bechuana appear to have had only very vague religious ideas, and their attention was chiefly occupied by the detection of wizards and witches. The word Morimo for God (also used in the plural to signify the Manes of the dead) appears to have meant a great and angry personage living in "the great hole in the North." Morimo sends the lightning-which in Bechuanaland is continuous for hours in summer, the storms being very violent, and the lightning unusually magnificent 
and destructive. The Hottentot Heitzi Eibib, who lives in a great hole, seems akin to Morimo. The Sechuana word for soul is Moia, meaning " breath," but they do not seem to have any expectation of future immortality. The ghosts of the dead are, however, believed to haunt the living, and to watch over their descendants. No idols or fetishes appear to exist among Bechuana tribes, and indeed Dr. Livingstone has remarked on this difference between the Bantu tribes and the negroes whom he encountered further north. As regards festivals, the harvest feast, as I saw it at Kunana among the Barolong, was celebrated with dances, songs, and drinking of Kaffir beer or brandy. The men assembled in a circle blowing on reed pipes and jumping round in a slow ungainly fashion. The women marched round outside, clapping their hands.

The initiatory rites of boguera (for boys) and boyali (for girls), will be well known to this Society. They are still practised among the northern tribes at least. Both girls and boys are organised in regiments, each regiment consisting of those within a few years of the same age. The boys of a regiment are circumcised when the chief's son, who commands them, is about 13 years of age. The beating of these boguera candidates with rods of Moretlwa (Grewia flava) was observed at Molepolole, capital of the Bakwena, by officers of the recent expedition.

Ordeals are noticed by Dr. Livingstone, namely, the Muavi, or drinking of goho juice by women, but on this point I gathered nothing new. As regards wedding ceremonies, there is one of casting an arrow into the hut by the bridegroom; which is worthy of notice as symbolic.

Among superstitions I may mention that of the "evil foot," which seems to correspond to the evil eye. After a birth no man is allowed for some days to enter the hut, and an infant is said to have died from the "evil foot" of a man so entering. It appears that tree worship exists among the pagan Bechuana. Mr. Mackenzie notices the habit of praying before the largest tree in a thick bush. A native entering a village on business will place a stone in the branch of a tree near the road, in order to obtain success in his affairs. I have seen these stones in trees. The custom is no doubt akin to that of Arabs and other Orientals of making cairns under trees, each visitor or passer-by adding a stone to the cairn.

The idea of the Totem may also, perhaps, be traced among these tribes. Many tribe names are derived from those of animals, as Batlaping from Tlapi "a fish," Batuana from Tao "a lion," Bakatla from Katla "a monkey," Bakwena from Kwena a "crocodile" The tribe is said to bina or dance before its sacred animal, and at the great council held by the Bakwena to meet 
Sir C. Warren the assembly shouted Makwen or " $\mathrm{O}$ crocodile man" at each point of the chief's speech. The crest of Sechele, chief of this tribe, is, I am told, a blue crocodile carved in stone. Mr. Mackenzie mentions that certain bushmen bina the common goat. It is unlucky for them to gaze on one, and renders them impure. The Bakwena also may not look at a crocodile and Livingstone tells us that they may not look at a zebra or quagga (Pitsi). A man bitten by a crocodile is exiled, yet the Bakwena will eat the flesh of the zebra.

The Puti or duiker, a kind of antelope (Cephalopus mergens) is sacred to the Bamangwato, whose chief, Kama, is named from another species, the hartebeest (Bubalus caama); and the hippopotamus of the Zambesi is said to be sacred to the Matabele.

There are also superstitions connected with fire. Mr. Mackenzie notes that if the rains are late all fires are extinguished and relighted by the lingakas or witch doctors, who make fire with the fire drill. These doctors are still powerful among the northern tribes. One was seen at Mafeking arrayed in necklace of teeth and hung with charms. They are distinguished from the moloi or wizards as practising white instead of black magic.

Some moloi were found in 1885 trying to bewitch the boundary line between the Bakwena and the Bamangwato. The latter made them swallow the liquor they had brewed, and with which I believe the boundary cairns were to be wetted. The unfortunate wizards died of their own poisons.

Mr. Mackenzie mentions the " digging of the garden of rain" a heathen ceremony. Charmed seed is planted in the corner of a garden before the sowing begins and the lingaka mount to the hill tops, blow horns and light fires and whistle and shout to bring the rain. They objected that the church bells of Kuruman kept away the rain. Sir Charles Warren on the other hand is held always to bring rain with him, and the rains were more plentiful in 1885 than for several previous years.

When the garden of rain has been sown it becomes unlawful to fell trees save at dawn or sunset, and a grave offence to bring a green bough of the Hackthorn (Acacia detenens) into the towns by day during the rainy season.

The lingaka (pl. of ngaka) receive presents of oxen in recompense for their labours. They are robed in baboon skin, and may sit on hyena skins. Children are frightened by being told that the moloi come unseen by night riding the hyena to carry them off. Among other unlucky things is the calling of a lion by his name Tao; he is called "the boy with the beard."

As regards birth, marriage and death, I have gathered little beyond what has just been said. There is a ceremony of 
purification after childbirth. Levirate marriage exists as among the Zulus, and exogamy seems the common practice resulting in a great mixture of tribal relations. The successor is the eldest son, I believe, in all cases save that of a chief, when " the son of the great wife" succeeds. The great wife may be declared at any time before death. Her son is not of necessity that of the chief. Thus Moshette, by native law, is senior to Montsiwa, being his nephew, son (by law) of the elder brother. I gather however, that Moshette was son of the widow only of the elder brother, and of a common man whom she married some years after the chief died. It is not considered proper in Bechuana society to speak of such a second husband, and the first child of such an union is always supposed to be the heir of the chief. As far as I can gather, this law does not apply to any but chiefs of tribes.

Polygamy and the paying of dower for wives do not seem to be customs attended with any great evils among the natives of Bechuanaland. All the women are married, and I fear it might be said that all (save those influenced by the missionaries) are as unfaithful to their husbands as are the husbands to their wives. As regards dower it should be noted that it forms a sort of marriage settlement. If a husband unjustly sends back a wife to her own people, she receives the cows paid for her as her portion. If she is justly divorced the cows are returned to the husband. The cows for the first wife are provided by the bridegroom's father: those for a second he has to get by his own exertions. A marriage "on credit" is however often possible, one or two cows being paid on account, the rest as the husband gets richer.

If a woman have an illegitimate child before marriage, the father pays so many cows, which when she marries are deducted from her dower. The native mothers are, however, vigilant, and in the old native society illegitimate children before marriage were few.

As regards burials, the chiefs I am told are sometimes buried vertically with bow and arrows and calabash of water. There are no sacrifices at burials, but pottery is broken by the widow over the grave. This I find is also a Chinese custom. No cemeteries are found near towns, for the grave is hidden. In some cases chiefs appear to be buried in their cattle kraals. These seem to be sacred places, and women are not allowed to enter a kraal while the cattle are in it. Among Zulus the spirits of dead chiefs inhabit serpents near their tombs, but this I have not heard of among the Bechuana tribes. Widows and widowers remain in huts outside the village, as being impure for a certain time after the death. 
Polygamy is said by missionaries to be decreasing, but this (except among converts) may be due to the decreasing prosperity of the tribes. Formerly, a man became richer the more wives he had, because they used to hoe his mealies. Now, however, ploughs have been introduced and the men take pride in driving a team of eight oxen in a plough. They are also proud of their wagons of sixteen oxen. The women are therefore less active in agriculture. It used to be a common sight to see a company of women hoeing a field, advancing in a line and singing in the intervals of labour. I have, however, very rarely seen women hoeing mealies.

The Bechuana system of government is somewhat akin to constitutional monarchy. The chief has certain counsellors representing each a village or section of the tribe, and each the head of a local council. The younger or less celebrated members speak first: the chief sums up. His decision is much influenced by the opinions of the counsellors who represent the popular wishes; but there is no voting and his decision is final. A good chief finds his tribe continually increased by families which desert the station of a cruel or incompetent ruler. The great fault of the system seems to lie in the power given to the chief, since, if a chief takes to drinking-which is too often the casedisorganisation and ruin ensue among the tribesmen-as in the case of the Batlaping, whose chief, Mankoroane, has illegally signed away the lands of his people, under the influence of drink given to him by white speculators.

The land laws are simple. The land belongs to the chief. He divides it among his head men, and they in turn among their people. There is no division of grazing land. The mealie fields are practically the property of their cultivators so long as they are tilled. I found each patch to belong to an individual, and to be divided generally by untilled land from the next patch. The fields have to be left fallow every third year at least, as the crop exhausts the soil, no manure being used. A chief can only legally assign untilled lands to new members of the tribe, whether white or black. The law as to theft is also very practical. The whole village is responsible. The head man must assist the person robbed, and the responsibility can only be evaded by proving that the spoor (for it is generally a case of horse, cattle, or wagon theft) extends beyond the village lands to those of another village. Thus the whole tribe becomes interested in detecting the thief.

As regards punishments I gathered nothing, but it is certain that white men have even been tried for their lives before Baralong chiefs. As a rule the legal and political proceedings of the Bechuana are remarkable for a love of justice and fair 
play, not always found among races higher in the scale of civilisation.

Native trade in Bechuanaland has now been ruined by the incursions of the white races. The evidence taken before a committee of which I was a member showed that before 1880, the Batlaping and Baralong carried on a considerable trade with Kimberley and Barkly in wood, skins, corn, and mealies. Even the Makalaka travelled south to work in the diamond mines until they had earned the price of a wife, and I have seen poor natives on their way to Kimberley, their only provision being a bottle of water. The trade is now extinct, and even the eniployment has fallen off through the misfortunes of the mining companies.

There is a good deal of hospitality between the tribes. Thus, the Batlaping, who were starving at Taung, went with their families in 1885 to visit Mafeking when the Baralong had a good harvest. These visitors were fed for a month and sent home with bags of mealies in their wagons.

The use of European clothing has become usual among the Bechuana, even up to the most northern part of the Bamangwato country, but in the small outlying villages the women still wear karosses, and carry their small naked children on their backs, tucked up in the skin. They commonly tie a bright handkerchief over their heads. In Mahiking the women wore print gowns and tartan shawls, and the men often wore the knitted bonnet of the Scottish lowlanders. Among the Batlaping, I am told the women continue, even under their skirts, to wear the heavy rows of beads round their waists; and they wear beads round their ankles looking like blue socks. There is much variety in fashion. One year all the women wear blue beads, but on another (perhaps just when a trader has laid in a stock of blue beads) the women all refuse to wear any colour but yellow. Just now very small black pot hats are worn by the men. Some years ago, huge felt hats, like that of Rip van Winkle, were in fashion. The stores are full of these hats now unsaleable. The children wear no clothes, but the girls have a fringe of leather reaching to the knees, and the boys a little skin apron.

I should note that the peculiar straw hat of the natives is still worn by men in some parts of the country. It is of very small size, like that of a Swiss woman, but much smaller. Sometimes it is even worn by young dandies set well on one side of the head.

The Bechuana are said to differ from the Zulus in living together in large towns with a few outlying villages or cattleposts, instead of being distributed in many villages of smaller 
size. Kunana, the largest of the native towns which I visited, contains perhaps 2000 huts, all of about the same size and all of one plan. The native hut is round, but sometimes a horse-shoe shape is now used, and square buildings erected in imitation of the white man. The roof is of grass on rafters of branches resting on a rough centre pole. The Barolong huts are much better built than those of the Batlaping; they are made of sun dried bricks covered with red mortar. The Batlaping use a sort of wattle of stakes and mud. The Barolong in the north make mudwalls to the yards, the Batlaping use scarrums of brushwood very neatly constructed to keep out the sand of the dust storms. The Barolong huts are very clean inside, and Mahiking, among its green trees and rocks, is a clean as well as a picturesque town. The towns of Kanya and Molepolole are still more picturesque, but, I understand, very dirty. In these towns a trader's house or tin shed may always be seen, and generally there are several.

The native fortifications consist of stone krantzes or walls, generally on the sides of Kopjes. We found Mahiking so fortified and Kunana as well; and the old krantzes of Chaka's time have been already noticed in this paper. These walis are thoroughly effective in absence of artillery fire. The native word for such defences is Litaku or "walls." It is curious to note how complicated some of these systems of walls may be made, allowing of desperate resistance after the fashion of street fighting even if the enemy should gain the first line of defence.

The towns are, however, in native estimation, still better defended by the charms of the Lingaka. Mr. Mackenzie mentions in his interesting work, "Ten years North of the Orange River," that lipeku or charms are placed on the roads outside the towns. These are generally horns of antelopes set up. This may perhaps only apply amongst Bamangwato, whose sacred animal is the antelope, puti. The lipeku ox is also sacrificed, being prepared some time previously by having its eyelids sewn together.

The Batlaping are perhaps the most degraded tribe of the Bechuana, and are despised by the Basuto who are more warlike and independent. Indeed, the Basuto are as yet an unconquered people. Nevertheless the Batlaping also can fight desperately as was shown by their refusal of the terms of peace offered, I am told, by Sir C. Warren, and by their subsequent desperate resistance at Takun or Litaku, a place named from its stone walls.

The Bechuana are now in possession of European fire-arms. The Barolong have a few good rifles-express or Westley- 
Richards-but not always the necessary cartridges. I have seen them parade with an extraordinary assortment of guns, from an elephant gun downwards. Some were the proud possessors of a cartridge belt for some sixty rounds, containing, however, only perhaps a single cartridge.

The old native arm was the chaka, or battleaxe. They never possessed swords, I am told. The shield was an oval of 18 inches by 12 , not the long shield of the Zulus and Matabele. The use of bows and arrows among the bushmen, in the western part of Bechuanaland, still continues. The arrows, I learn, are poisoned with the milk of the spurge (Euphorbia), or by being left in decaying animal matter, or-according to others-by the poison of snakes. The arrow has a long and fine iron blade, sharp as a razor. The varieties of native arms may be studied in Mr. Mackenzie's book above mentioned.

Turning from war to the chase, it may be noted that among the Bangwaketse and other more northern tribes, the hopo, or game trap, described by Dr. Livingstone, is still in use. I found old game pits further south, but near Korwe (a place named from the hornbills which abound in the vicinity) I found one recently prepared. Game is gradually disappearing south of the Molopo, though it is still abundant in the west and north. The lion still occasionally ranges as far south as Taung (a place perhaps named from this beast), and the spotted cheetah is still common in the west, but the elephant and the giraffe are not found in the new colony. The wildebeest, hartebeest, quagga koodoo, stein-buck, duiker, riet-buck, gems-buck, springbok, blesbok, and occasionally, I believe, the rooibok (pala) are still found in numbers in the less frequented parts of Bechuanaland. The hopo which I saw consisted of forty pits arranged in fours, the length of the trap being in the direction of the drive, which was cleverly constructed of thorns-a sort of hedge not conspicuous, but difficult to pass. The pits were 3 feet by 4 feet, and 4 feet deep, with narrow ridges between. I am told that a cavalry horse was disabled, in another part of the country occupied by the expedition, having been ridden into a buck pit during a hunt.

Bechuana society may be considered to consist of four grades beneath the chief. The rich men-sons of chiefs or counsellors - generally of the chief's family, live in the native towns and possess herds of oxen, mealie fields cultivated by their retainers, and wagons driven by their servants. Beneath them comes the agricultural population, also living in the towns, engaging in trade and in native manufacture. The herdsmen, who keep the herds at the cattle posts, are again a lower class, and the poorest are the Makalahari,who are nomadic hunters, living chiefly in the 
west, and considered in the light of serfs of the chief. These Makalahari are, in condition, similar to the bushmen, but the true bushmen are not Bechuana, but Hottentots, or akin to the Hottentot, judging from the linguistic evidence. Even the Batlaping still claim authority over bushmen living on the borders of the Kalahari Desert. ${ }^{1}$

The chief native manufactures are in leather and in metal. The native smiths are said to be skilful. They use a bag bellows, like that used by gipsys all over the world, which I have seen in Italy and in Syria. They draw copper through holes in a stone to a fine wire. I have, however, never come across any smiths. The Mashona, living in a metalliferous region, north-east of the Matabele, are famous for their metal work, and for the copper ornaments of the women. In the south, Europeans are now employed to mend the ploughs and the wagons of the natives.

The manufacture of karosses continues to be one of the great industries of the Bechuana, and these skins are retailed at a high profit by traders in Kimberley market. The tiger skins are brought from the north, but deer skins, blesbok, koodoo, or more commonly springbok, may be obtained anywhere. Jackal skins and cat skins are among the softest. The skins are suppled in milk, they are tanned with mimosa bark, and the sewing is remarkably neat, a button-hole stitch being used (as I am told by Mr. Ashton) the sewing material being a fine sinew of the animal. Every shot hole or spear mark is carefully patched, and this is often so well done as to be invisible on the outside. Sheepskins are also made into karosses, and form excellent beds. It is usual to wear the needle used in sewing karosses suspended round the neck, in a wooden case as an ornament.

Stone implements in South Africa seem to be chiefly represented by the "bushmen stones," which have often puzzled explorers, being found in deserted settlements. It appears to be thought that these were used as weights on the sticks or stakes used by the bushmen in digging for ronts, but they do not seem to be now in use. The stone is globular, and the perforation is shaped so as to be smallest in the middle. This may perhaps result from being bored on both sides.

As regards education, considerable progress is made by individuals. Schools have been established by missionaries, and appear to be well attended. A native newspaper has long been published at Kuruman. The nephews of Montsiwa were able to speak. read and write English, and even to understand a map, and draw a rough plan of the roads, with names of places

\footnotetext{
' Bushman pictures are to be found in Bechuanaland, east of Vrijberg, but I was unable to visit the spot.
} 
written in English characters. I have no doubt that their education extended even further, but confine myself to personal observation. The sons of Sechele, I am told, have even composed hymns in their native tongue, but this has not prevented them from falling into habits of intemperance. They were educated in Cape Town, but a native can now receive an elementary European education even at Shoshong. Dutch is more spoken, however, than English, especially by the natives near the Transvaal, but there are many natives who can speak the three languages-including their own.

Native children are a cheerful race; and indeed, in spite of war and famine, the Bechuana are a cheery people, always ready to laügh and sing, and easily forgetting their troubles. The children do not appear to have many regulir sports, but are found in every village riding on sticks or cracking whips. They also make little toy huts and kraals; and one officer brought back a small ox made of clay and very fairly formed. These oxen they place in their miniature kraals.

One of the last questions in the text book which I have followed, relates to conservatism and variation. Concerning this, I may say that the natives of South Africa, like the Arabs, are by no means blind admirers of civilisation. They have their own opinions, both as regards individual white men, and also respecting individual white customs or inventions. They regard their own customs generally as being best fitted for themselves, but are willing to accept such improvements as commend themselves on the score of utility. Thus, the wild Bedawin of Syria have adopted firearms, cigarettes and matches, but have not taken to European clothing, or to tall hats. The Bechuana have adopted ploughs, wagons, firearms, hats and European clothing, also brandy, and gold, silver or copper coins. On the other hand, they are attached to their old system of land tenure, and do not always desire to be converted into individual independent farmers under government. Neither do they always recognise the superiority of the Christian religion over their own cruel and stupid superstitions. Nor again do they desire only to have one wife. They regard the payment of dower as a mark of respectability; and the physique and morality of the race-though the latter has never been goodhave deteriorated, in consequence of the loss of self-respect and of the decay of the native system of society.

In conclusion, I would venture to assert that our present treatment of the native race in Bechuanaland reflects little credit on us as a nation. It is true that we do not-until attacked by the natives-destroy their villages, nor do we shoot their wumen and carry their children captive as the Boers 
still do, but the native outbreaks are, as a rule, the result of oppression and injustice on the part of white men. Starvation and the illegal seizure of native lands are, perhaps, slower, but not more justifiable, methods of securing that retreat of the black man before the white which Colonial politicians seem to regard as a mysterious action of natural law.

Were such action followed by material development of the resources of the country, we might perhaps regard the result with more satisfaction, but Lord Wolseley was certainly right in saying, only the other day, that the Boer is little above the native in the scale of civilisation. He is, indeed, in some cases lower, for he does not, like the Bechuana, desire improvement, and the extension of trading operations. Were it possible for independent Englishmen to take up the settlement of native questions, on the basis of equitable recognition of all claims irrespective of race, we should, I think, hear little of native outbreaks: and if the Bechuana chiefs were supported in their attempts to keep brandy out of their towns, we should not have to chronicle the final disappearance of the race of which I have thus offered you a slight contemporary sketch.

\section{Discussion.}

The Chairman (Mr. Hyde Clarke) after referring to the services and claims of Captain Conder, said that it had been an object of the former President, General Pitt-Rivers, that the Antbropological Institute like other learned societies, should in the course of its session have papers on the topics of the day. He considered that if anthropology was to be made a popular study, so also it must be shown to have its practical aspect. These meetings bad been inaugurated by the late Sir Bartle Frere in the President's house in a discourse on South Africa, which was a fitting prelude to this paper of Captain Conder. It was more than possible that the observations of Dr. Bleek and others had some foundation, and that clicks, tones and intonations were connected in the origin of language, with the same causes of differentiation, which produced tones in the Chinese and Indo-Chinese languages. Such were not to be considered as having been invented by the Chinese.

Mr. Carmichael, having taken the Chair vacated by Mr. HydeClarke, observed that among the various points of interest which struck him in Captain Conder's account of the Bechuana and neighbouring tribes one was that of their superstitions and folk-lore, and in connection with that topic he desired to mention, besides the Blue book referrea to by Captain Conder, the interesting draft Penal Code for the Transkei, of which an account was given in a recent number of the Cape Law Journal (Grahamstown) for June, 1885. That code was, he thought, probably the only existing code to which we could turn for an authorised statement of the folk-lore 
and superstitions (e.g., witcheraft) of uncivilised races in so far as they touch upon social order. We had had, and it might be said, still had plenty of superstitions in England, and occasionally, as in the case in which William Rufus is known to have sneered at his English subjects for their superstitiousness, the facts have got on record in our history. Mr. Carnichael wished to know, with regard to the dances mentioned by Captain Conder, whether he saw any evidence of their having any astronomical connection, like the dance at the return of the Pleiades, stated to be a ceremony among the bushmen, and with regard to the expressions used concerning the whole tribe as being interested in the apprehension of a thief, whether he might take that to mean that collective responsibility was a Bechuana institution. In moving the thanks of the meeting to the reader of the paper, Mr. Carmichael referred to the pleasure which it gave him to have that opportunity of thanking Captain Conder for his valuable services in the cause of scientific exploration, of which he had, on a previous occasion heard him give an interesting account, at a conference at South Kensington in connection with the Survey of Palestine.

Mr. W. Morrison, called attention to the chiefs being darker in colour than their subjects. As a rule the governing class of a tribe were lighter, not being so much exposed to the sun. Was there any other example of the $D$ being confused with $L$ and $R$ ? The confusion of $L$ and $R$ is common in the Pacific Islands. Another example was Lima, which the early conquestadores wrote as Rimac.

Mr. BERTIN said that he should like to call the attention of Captain Conder to the ethnological differences between the bushmen and the Bantus which Captain Conder in his most interesting paper seemed not to take sufficiently into account. He spoke of the Bechuanas for instance as having the hair in tufts, which is a bushman characteristic ; the clicks also were, according to Bleek, Professor Keane, and others, bushman in origin. As for the tones found in Hottentot and other African languages in the South as well as in the Niger region, they could hardly be taken as a proof of relationship of two races, for we know how and when they were developed in Chinese: and, as noticed lately by Professor Terrien de la Couperie, tones were now being independently developed in Tibetan to compensate phonetical losses. Of course the intermingling of the populations was so considerable in South Africa that Captain Conder had had many difficulties to overcome in his interesting and thorough study of a race, which, if it did not pass away would, in course of time, be so completely modified that for the ethnologist and philologist it would have practically disappeared.

Mr. Chesson, after thanking Captain Conder for his interesting paper, which he said had been pervaded by a true spirit of humanity, referred to Secheli's desire to establish a prison in his territory for the punishment of criminals. He remarked that the late Bishop Colenso had informed him that Cetywayo, on the eve of the Zulu war, was meditating the introduction into Zululand of a similar 
institution. Generally speaking, a savage chief, not knowing what to do with his criminals kills them, but the fact that both Secheli and Cetywayo conceived the idea of largely substituting imprisonment for capital punishment, showed a great amenability on their part to civilised ideas of justice. He was glad to hear what Captain Conder had said about the purchase of wives for cattle among the Bechuanas. He could, however, assure him that that system in Natal and elsewhere was fruitful of great evils, and that it often placed young women, whose affections were otherwise engaged, at the mercy of old and wealthy polygamists. He thought that in countries which came under British rule the system ought to be gradually abolished. With reference to intoxicating drinks, he hoped that the Bechuanas had the same power of moral recovery as the Basutos, who after having yielded to the insidious temptations of Cape brandy, and apparently lost all self-control, suddenly awoke to a sense of their degradation, and expelled the brandy bottle from their country. After referring to the cruelties of the Boers to the Korannas, and especially to the neglect of the wounded after the capture of Mamusa, Mr. Chesson thanked Sir Charles Warren and Captain Conder for the good work they had done in Bechuanaland.

The Rev. J. Mackenzie, expressed the great pleasure which he felt in finding an assembly of learned men in London discussing the subject of Captain Conder's paper. And he was especially gratified with the clear manner in which Captain Conder had put together the observations contained in his paper, which abundantly proved that he was both an able and a trained observer. He might be allowed to supplement, or explain further, one or two matters. In Bechuanaland the cattle paid by the bridegroom under native law to the bride's father was the only way in the olden time of establishing the validity of the marriage and the legitimacy of the children. Without the payment of cattle the father could not establish before natives that the children were his. But Christian natives were getting accustomed to the marriage register in the native church as a still better proof of marriage, of the consent of the father.inlaw and other relatives, and of the legitimacy of the children. The morality of mission stations was higher than that of the heathen towns; only cases of immorality were observable in the former, while unnoticed in the latter. There was no point to be made out in favour of the English as such or the Boers as such. The difference was one of education; the stock or race was one and the same. It was as if two sons of the same parents had chosen different courses-one remaining among educative and civilizing influences, while the other shouldered his rifle and went into the wilderness. It was quite true that so far as we knew there were not 200,000 people in Bechuanaland from the Cape Colony to the Zambesi. And yet in some parts of the country natives might suffer hardship through loss of their cultivated lands. But under wise administration and control it was certain that there was land in Bechuanaland not only for the natives but for a considerable 
population of Europeans also; and the advantage to all parties would be very great if the English Government assumed the management and control of this wide area of unoccupied land. The question had just been put if it was absolutely indispensable that strong drink should be sold at Mankorrane's town. He was not aware of any necessity for this. The Administrator was free to decide either for or against it. The law in the new colony on the whole was that of the Cape Colnny. But there was no colonial law compelling the sale of liquor or the licensing of canteens, although such houses might be legalized under certain restrictions. It was not according to colonial practice to issue a licence to sell drink within a native town. In the Free State they had no canteen licences whatever. If nothing but ginger beer were for sale in Taung the missionary would not have attended the licensing court to protest against the issue of the licence, nor would the magistrate, the son of Dr. Moffat, have thought it necessary to explain that in this matter he had consulted the Administrator and that the licence to sell spirits in Taung was issued by the desire of the Administrator himself. At the same time he would not have them believe that the Bechuanas were a drunken people, or that natives generally were dying out in South Africa. This was not so, from all the information which he could obtain. Although the natives had no large idols as in other countries, they had smaller fetiches which they wore or placed in their dwellings, and in which they trusted. They believed in the after-life of man, and were ancestorworshippers.

Sir George Campbell, and Mr. C. Roberts also joined in the discussion.

Captain CONDER, in answer to the questions raised in discussion spoke as follows:-The dances to which I alluded are not of certain antiquity; I do not think they have any discoverable astronomical origin. Both men and women moved round, not with, but against the sun. As regards the size of the chiefs (to which Mr. Morrison alluded) the chiefs are generally much stouter than other natives, chiefly, I suppose, because they are better fed. As regards the word Turanian, I wish to say that I used it in the present restricted sense as referring to the Altaic race which is certainly known to have existed in Babylonia as early at least as 2,500 B.c.

I am, of course, aware that the Bantu Hottentot races are quite distinct. It is possible that the tufted hair of some of the Bechuana may be due to an admixture of Hottentot blood.

The chief questions raised in discussion referred to trade, sparsity of population, drink and disease, and to the treatment of the Korannas by the Transvaal Boers. I think that there is a good deal of misapprehension in England on each of these questions which affect the future of the natives of Bechuanaland.

As regards trade, that of the natives has ceased entirely since the incursions of the filibusters from the Transvaal ; and the Batlaping having been deprived of all their best lands are now not only without the means of carrying on such trade but even without the means of subsistence. The white trade with the interior was 
almost entirely in the hands of Englishmen. This also has been much injured by the filibustering incursions, but may revive. That of the Batlaping natives is, however, quite ruined.

As regards sparsity of population the natives are collected in towns chiefly. There is much fertile land capable of cultivation if wells, cisterns, and water furrows were made. This the natives have never learned to do. There would be plenty of room for both whites and natives if the latter were allowed to retain their cultivated lands round the natural sources of water supply, but from many of their lands they have now been driven off and are over-crowded on the small remaining part of their original lands.

It is quite certain that Cape brandy is now being very largely consumed by the natives within the Crown colony. The rule of Montsiwa, Kama, and other chiefs was formerly so strong that the white traders did not dare to deal in spirits as they would have been expelled and would have lost all their other trade had they been found to deal in spirits. The drunkenness of the southern tribes is far more general than that among the northern.

The disease to which I referred (syphilis) is fearfully prevalent among the Mari Batlaping. It is also wide-spread among the Batlaping of Taung. In the north among the Barolong, it appears less general. It is generally attributed to the white people. The congenital diseases of the children appear to be such as would result from the parental syphilis, and these congenital diseases are said by old residents to be much increased. The climate is very healthy, and is specially recommended to consumptive Europeans so that the lung diseases do not seem to be due to climate.

The treatment of the Korannas by the Boers during the present year is notorious. This is, however, a political question. Moshette, the Barolong chief at Kunana, is said to be already marked out by the Boers as a victim, and the future treatment of this chief should be noticed by those who may feel interest in the question.

It was not my intention, however, to do more than refer to wellknown facts in the recent history of the Bechuana in a paper of a scientific character. 